\title{
Varieties of spiritual individualisation in the theosophical movement: the United Lodge of theosophists India as climax of individualisation-processes within the theosophical movement
}

Helena Blavatsky's 'Theosophical Movement', founded in 1875 in New York, shows itself in its beginnings as an example of detraditionalisation from conventional forms of religion. This is associated with an opening for individual and experimental approaches to new and foreign forms of religions and spiritualities. The later increase in institutionalisation within the movement provided less space for this sort of individuality and led to divisions and splits within the movement.

This chapter aims to identify and extract the specific dynamics of processes of individualisation, as well as de-individualisation, within the theosophical movement in the form of a step model. The latter in the United Lodge of Theosophists' (U.L.T.) 'method' and individual approach to Helena Blavatsky's theosophy, which has as its sole focus the pursuit of the individual and its perfection. This pursuit is understood as an act of unification with the Divine or higher self, as well as with the community of likeminded persons, in a way that is both individual and vital, as well as providing a service for humanity. Certain features of this process are methods for an ultimate elimination of disturbances that obstruct the study and spread of the true teachings of Blavatsky, seen as a manifestation of divine wisdom. However, an essential component of this process is the realisation of one's own, individual path.

\section{Introduction}

The Theosophical Society (TS), established in 1875 in New York, introduced a perspective on the world that its founder, Helena Petrovna Blavatsky, later defined in the subtitle of her Opus magnum opus, 'Secret Doctrine' (1888), as a 'Synthesis of Science, Religion, and Philosophy’. The society had as its first and most important objective the forming of 'a nucleus of the Universal Brotherhood of Humanity, without distinction of race, creed, sex, caste or colour'. Their second explicit aim, with which I will be concerned in this chapter, was to gain deep insights 
both the sciences and the wisdom contained in world religions ('to encourage the study of comparative religion, philosophy and science'), for the purpose of individual spiritual perfection and self-divination ('to investigate unexplained laws of Nature and the powers latent in man'). ${ }^{1}$ This second aim offered manifold possibilities for spiritual individualisation. ${ }^{2}$ This de-traditionalisation from conventional forms of religion and spirituality, parallel to an opening up to individual and experimental approaches to new and foreign forms of religions and spiritualities, climaxes in the United Lodge of Theosophists' (ULT) programmatic individual approach to Helena Blavatsky's theosophy.

This chapter aims to identify and extract the specific dynamics and the development of processes of individualisation (and de-individualisation) within the theosophical movement. ${ }^{3}$ It can be regarded as a step model, beginning with the foundation of the TS in its specific historical and geographical environment and culminating in the concrete implementation of the ULT 'method' as a possible peak of spiritual individualisation within the Theosophical Movement. These processes and varieties of spiritual individualisation within the history of the Theosophical movement can be defined generally as dynamic, partly reactive, and sometimes backwards, even in the sense of de-individualisation. The ULT (India) represents one of the movement's programmatic climaxes and can be seen as a special example and 'methodology' for reactive spiritual individualisation. In the following, I will outline the particular gradual process of spiritual individualisation, which starts with the formation of the Theosophical Society in 1875 in New York as the breeding ground of previous global spiritual and scientific currents. ${ }^{4}$

1 This is the most prominent version of the 'three objectives'. For the history of revisions and modifications see. http://theosophy.wiki/w-en/index.php?title=Objects_of_the_Theosophical_ Society (last accessed 5th August 2018).

2 I prefer to use the term 'spirituality' because of its more 'inclusive' connotation, which more suitably represents the Theosophical Society' self-image.

3 In doing so, it is important to distinguish between generally visible tendencies within the movement and their consequences, and highly individuated individuals at the top, such as Helena Blavatsky, Annie Besant, or Bahman Pestonji Wadia. The latter have been the subject of a number of studies and are not central for this discussion. See, for example, on Helena Blavatsky: Cranston 1993; Goodrick-Clarke 2004; Keller and Sharandak 2013; for Annie Besant: Taylor 1992; for prominent Indian theosophists: Moritz 2017.

4 Part III, Theosophy, Culture, and Society, in Hammer and Rothstein 2013, provides an overview with different topics. For detailed information on the spiritual precursors, see Godwin 1994. 


\section{The beginning: the theosophical society (New York, 1875) as a platform for individual religious options and a provider of 'ancient wisdom'}

First, it will be useful to embed the genesis of Blavatsky's Theosophical movement into the context of socio-religious, occultist, philosophical, and scientific traditions and events spanning global history. ${ }^{5}$ Of particular interest for the topic at hand are those traditions and events that were well-known to Blavatsky and explicitly mentioned in theosophical sources, such as in the presentation of 'classical' Theosophy as a quest for divine wisdom (Goodrick-Clarke 2013). Scientific discussions on evolutionary theories, new archaeological discoveries, psychology and occultism, as well as social challenges were important issues. Finally, a main source for Blavatsky's incorporative theories on the rise of the human race and the link between the cosmos and its spiritual development were Indian religions. This background provided arguments against the rising 'purely materialistic' Darwinism and provided, in her opinion, a 'natural', magical worldview (Bevir 1994, 748; Haas, forthcoming).

The importance of spiritualism and its establishment in the Anglo-American urban intellectual middle and upper classes in particular, increased in the late 19th century. The growing interest in spiritualism, and in consequence its commercialisation, generated accusations of fraud against dubious mediums and their activities. This in turn led to a loss of reputation, but also to investigations about 'different possible realities', first and foremost by the academic field of psychology in the United States. ${ }^{6}$ Finally, a literature-based, culturally-interactive avantgarde spirituality, triggered by various religious, utopian- and reform-movements, ${ }^{7}$ post-war-experiences, ${ }^{8}$ 'new' sciences including psychology (Taylor 1999) and

5 This kind of examination was - and is - extensively done in the relevant secondary literature, e.g. Bevir 1994; Godwin 1994; Lubelsky 2012; Hammer and Rothstein 2013; von Stuckrad 2014.

6 Such as the Society for Psychical Research.

7 The western and central regions of New York state at the time of the Second Great Awakening, was termed 'the burnt district' by Charles Grandison Finney in 1876, who defined this area as 'over-evangelized' and without any unconverted population left over to be 'burned'. See Cross 1950; Wellman 2000; Pritchard 1984; Altschuler and Saltzgaber 1983. This region became fertile ground for many of the new religious and reform movements who later permeated almost all parts of society, e.g. Transcendentalism in literature, Utopian groups (e.g. Shaker-movement), as well as Protesting-movements as the Women's rights movement, the American labor movement, Abolition movement, Prohibition or Temperance movement). Surveys are Sutherland 1989; Schlerth 1991 Claybaugh 2007. For the Women's rights movement: Braude 2001.

8 The popularity of spiritualism gains in importance especially after periods of war (American Civil War 1861-1865 and WW I 1914-1918), when people had suffered the loss of relatives and 
parapsychology, as well as a growing interest in- and knowledge of eastern spiritualities became the fertile soil of the movement (detailed information in Carroll 1997). ${ }^{9}$ Spiritualism and the quest for scientific proof of the existence of spirits and supernatural phenomena thus turned into a matter of interest for the intelligentsia, especially in North America. Knowledge of non-Christian and, in particular, Asian religions and wisdom systems was common and widespread in these circles (Christy 1932; Bergunder 2006). This is equally true for the idea of universal religion (Transcendentalism and Unitarianism are to be emphasised here) as a result of one of the central themes of 19th century scholarship: the search for origins.

When considering North America in particular, a close connection between spiritualism and Protestant forms of religion and their ideals should be taken into account, manifested, for example, in a commitment to reform in the areas of women's rights and the abolition. This factor will later be particularly interesting with regard to Olcott and his Buddhist activities in Sri Lanka (Prothero 1995 and 2006). The rising importance of modern science should likewise be seen in direct relation to these phenomena in the light of industrialisation and the pioneering discoveries of the (natural) sciences during the 19th century, the latter became increasingly influential. A transformation process from 'faith' to 'plausibility' had to be warranted by 'knowledge'. Therefore, as well as to demonstrate scientific claim, many religious communities labelled themselves as 'scholarly' (Stuckrad 2014). ${ }^{10}$

As a matter of fact, a fertile tension arises from these seemingly conflicting issues of science, spiritualism, and world-religion. This tension can be considered the basis for the genesis of the Theosophical Society's program. According to the protocol ${ }^{11}$ of the first meeting, the society was originally formed 'for the study and elucidation of occultism' in 1875 in New York by Helena Blavatsky, Henry Steel Olcott, and William Quan Judge, who had all been involved in spiritualist circles before. Thus, they were quite aware of the scientific examination of spiritualism

loved-ones and were willing to try new ways to get in touch with them. A prominent post-WWI-example is Arthur Conan Doyle, creator of 'Sherlock Holmes'. Conan Doyle wrote numerous books on the subject, among them The History of Spiritualism (1926). For background and reasons for the spiritualist 'hypes' see e.g. Oppenheim 1988; Hick 1990', 129-76; Carrol 1997; Albanese 2007.

9 Italicised sentences show the plot of each section in this chapter.

10 Blavatsky often commented very harshly on the academics of her time and their 'dogmatics'. See Haas 2012 and forthcoming.

11 Notes of meeting proposing the formation of the Theosophical Society, New York City, September 8, 1875: http://upload.wikimedia.org/wikipedia/commons/a/a8/St-1ata.jpg (last accessed 6th June 2017). 
by scholars; the zeitgeist influenced them to work from similar motives and - at least in theory - for the same purpose.

In terms of religious individualisation, for this initial stage of the TS it can be stated that the aim was solely the scientific study of the occult, which was later combined with the desire to acquire knowledge of universal laws and their dissemination. According to Olcott, the ideal of Universal Brotherhood as the 'first objective' was developed later, around 1878, and was not part of the original concept but merely a necessity with regard to the intended association with Asians. ${ }^{12}$

However, acquisition of knowledge of world religions and their ancient wisdom was seen as necessary for each member's individual 'pool of knowledge' and as a basis for finding their own path. Therefore, it is fixed as 'the second objective of the TS': 'II. The study of ancient and modern religions, philosophies and sciences, and the demonstration of the importance of such study'. Knowledge as an objective of individual searching should, the society believed, originate from pure, ancient traditions in their original form, which are to be preserved. Established, traditional, forms of religion were perceived and criticised as corrupt or obsolete.

The third objective, 'III. The investigation of the unexplained laws of Nature and the psychical powers latent in man', was thoroughly modern for its time and is connected, inter alia, with the emergence of psychology as an academic discipline. It should also be noted that the idea that Asian religions in particular were important carriers of religious experiences emerged in close connection with the inception of psychology. Some psychologists have considered William James' The Varieties of Religious Experience (1901/02) to be an early example of a combination of scientific acceptance and study of the existence of the unseen, which modified the common, merely materialistic idea of the sciences. ${ }^{13}$

12 'The idea of Universal Brotherhood was not there' and did not occur until in 1878, the Society's 'sphere of influence extended so as to bring us into relations with Asiatics and their religions and social systems', thus making 'the Brotherhood plank [...] a necessity, and, in fact, the corner-stone of our edifice'. The by-laws adopted in 1875 simply state, 'The objects of the society are to collect and diffuse a knowledge of the laws which govern the universe'. Olcott, cited by Anonymous 1951, 45 (last accessed 9th August 2018).

13 James was a member of the TS branch in Boston (no longer existent) at that time. This information can be found with reference to Blavatsky-biographer Sylvia Cranston in Taylor 2009, 50, n. 58: 'James had been a member of the Theosophical Society in Boston since 1888, read their literature, and commented regularly upon it, particularly in The Varieties of Religious Experience (1902a). [...] Acknowledgments to Sylvia Cranston for providing me with documentation for James's membership in the earlier Theosophical Society'. The significance of the paranormal for late 19th century psychology and William James in particular is portrayed in an interview with Eugene Taylor by Thibaud Trochu (2008). For further reading, see Taylor 1983 and Blum 2006, as well as the critical review by Taylor 2007. 
One additional, and equally important, factor regarding the supposed tendency towards religious individualisation in the initial phase of the movement is the fact that Blavatsky had already been familiar with (Tibetan) Buddhism for a long time. She even called her apartment in New York 'Lamasery'. Olcott was also interested in Buddhism during this period in New York and had at least a basic knowledge of both ancient texts and discussions about Buddhism's 'modern' forms. ${ }^{14}$

Buddhism contains immense potential for individualisation in its basic assumptions and in the sometimes explicitly anti-dogmatic nature of its teachings, such as the direct invitation of its founder to act solely according to one's own experience and to accept as ground-breaking that which has been recognised by each individual as right. Nothing but serious reflection on one's own experience can, in combination with the acceptance of the 'four noble Truths' and other universal laws, lead to escape from the cycle of rebirths. This is certainly one of the key reasons behind the wide range of possibilities offered by the TS for an individual approach to religion, religious experience, and spiritual liberation, which is free from any convention about 'What is to be believed'. The Theosophical Movement in its initial stage therefore creates a fundamental platform of possibilities for religious individualisation by offering and at the same time requiring the study of world religions and their wisdom, as manifested in their 'second objective'. This should prompt the individual to search for his or her own truth by using the knowledge gained. Moreover, the existence of both a spiritual world and the paranormal is a natural assumption, while commercial spiritualism is officially rejected.

Any kind of traditional religious confession or belief therefore becomes irrelevant and is subsidiary to the idea of Universal Brotherhood. At the same time, the fundamental necessity of studying the human psyche is emphasised as an absolute requirement in the face of massive upheavals in matters of faith through new, spiritual-religious currents and their confrontation with the realities of their time.

Finally, the focus on individual religious needs is to be taken into account within Universal Brotherhood.

\section{Activities and interactions in India}

In order to discover whether religious individualisation may have been triggered by the TS's various interactions with indigenous religions and existing religious movements in India from 1879 on, in what follows I examine them in their own broader historical and intellectual contexts. Here, observable phenomena are

14 For discussion on the specific ‘Buddhisms' of Blavatsky and Olcott, see Haas 2015. 
characterised by great diversity and can only be recorded based on individual, particularly significant, phenomena as shown below:

1) The (very short) 'fusion' with Dayananda Saraswati's Hindu reformist movement Arya Samaj (Anonymous 1951, 59; Campbell 1980, 77) failed after a short time. The reasons for this failure were twofold. On the one hand, regarding content, the relationship was blocked by Saraswati's basic assumptions that all non-Vedic teachings are heresy, that there is one sole ruler to be worshipped, and that the Veda is the exclusive source of true knowledge. On a more psychological level, Sarasvati's claim to supremacy soon collided with the TS's founders' popularity and their need for recognition. The first issue, in particular, conflicts with (and is absolutely contrary to) the concept of an individual approach to religion, which was based in part on the TS's founders' tendency towards Buddhism. Finally, the fusion resulted in the Theosophists' 'conversion' to, and emphasis on, the superiority of (Theravada) Buddhism, ${ }^{15}$ the fundamental claim of which is that the individual finds his or her way to (self-) salvation without god or institutions.

2) The interaction with the Parsees in Mumbai eventually resulted in 'Parsee Theosophy' ${ }^{16}$ This special form of Zoroastrian religion includes e.g. the reestablishment of occult elements, such as the reintroduction of Avestan as the ritual language, the introduction of reformed rituals with a new emphasis on the occult content, as well as the combination of traditional theological concepts with scientific terminology. This created a new form of metaphoric Avestan hermeneutics and was advocated for by the Theosophists. It additionally agrees with the traditional notion of faith in a personal god, as well as with the intermediary role of a priest. Indeed, Parsee Theosophy can also be interpreted as a counter-movement to the simultaneously increasingly fashionable Western textual criticism and the corresponding interpretation of tradition. As such, it is, however, a phenomenon of the elites and the educated classes who are aware of the related debates.

Even though Parsee Theosophy is a side effect affecting the (minority) religion of the Parsees more than the Theosophical Movement itself, Parsee Theosophy is a still ongoing result of and reaction to preceding religious individualisation within the community and is therefore based on partly

15 For details, see Haas 2015.

16 A brief description of the rarely used term Parsee Theosophy as a separate category can be seen in the online encyclopedia Overview Of World Religions of the Division of Religion and Philosophy at the University of Cumbria: http://www.philtar.ac.uk/encyclopedia/zorast/partheo. html (last accessed 8th June 2017). The origin of the term parsi/parsee is usually traced back to 'those from Persia', and does not signify any religious affiliation. See Stausberg 2002, 373. 
re-traditionalising and 'esoterising' the Zoroastrian religion within the Indian Diaspora. It can thus be summarised as a process, triggered by the Theosophists, of religious individualisation based on re-traditionalisation by 'regaining lost spirituality'.

3) As to the Theravada Buddhism of Sri Lanka, the intermediary work and popularity of Henry Steel Olcott from the 1880s onwards was both responsible for its revival and the cause of a major boost, through his setting up of infrastructure and his support for religious networking among the various Buddhist traditions of Asia. The explicit preference for Theravada Buddhism by Olcott and Blavatsky, seen as 'representatives of the West', raised new confidence among the Sri Lankan Buddhists (Campbell 1980, 84; Bechert 1995, 336f.; Queen $1996^{17}$ ).

With regard to religious individualisation there must be a clear distinction between a) the potential of extension of individual paths in the West ('Western Buddhism') inspired and enhanced by Theosophical Buddhism, and, on the other hand, b) the creation of stimuli within the existing Sinhala Buddhism. Olcott's perception and reforms of Buddhism play an essential role for Western recipients: his 'Protestant Buddhism', as it was defined by Obeyesekere (1970) and Prothero (1995), represents a new variety of Buddhism, using methods derived from, among others, Christian missionaries. ${ }^{18}$ It idealises and simultaneously hybridises Buddhism with the ideas of the Theosophists and therefore turns it into a religion more easily 'digestible' by interested Westerners than contemporary Buddhism as it was actually practiced. In this way, Prothero states, Olcott turned out to be the 'first Western Buddhist missionary'.

4) Compared to what I have outlined so far, the role of Annie Besant appears much more diverse and less specific in terms of spiritual or religious individualisation. The reason for that is a permanent tension between spirituality and politics that defines her person and activities. In many respects, this can be recognised as the result of her political commitment. It specifically manifests in, for example, her significant affinity for Brahmanism in her later Theosophical life, as well as in a clearly evident, increasing hierarchy in the movement during her presidency, along with the creation of (public) cults

17 Queen 1996, 21ff. identifies Olcott, Dharmapala, and, finally, Ambedkar as pioneers of the so-called 'Engaged Buddhism'.

18 A discussion of this term is given in detail in Prothero 1995. According to him (1995, 281), the basic, simplified typology is as follows: 'Obeyesekere intended the term to convey two meanings: first, that this new form of Buddhism began as a protest against Christian missions; and, second, that it mirrored Protestant Christianity in structure and content'. 
(Krishnamurti, etc.) in the TS Adyar. The latter tendency, in particular, eventually led to the resignation of her co-worker BP Wadia (and many others), who then joined the (U.S.) United Lodge of Theosophists and later established this group in India.

Religious individualisation, based on the interaction of theosophy and indigenous religions, is largely characterised by the mutual influence of Besant and parts of the Brahmin elite. However, this too - as in the case of Buddhism and Olcott in Sri Lanka - was preceded by a variety of activities from pre-existing Hindu reform movements and was often even inspired by colonial presence and Christian missionary activities. Thus, the TS in India had already gained some influence among Indian elites even at the beginning of Besant's active time. Individuals such as Bhagavan Das, with whom Besant founded the 'Central Hindu College' (CHC), now 'Benares Hindu University', at Benares, should be mentioned here. For the education of young Hindus, she authored an introduction to Hinduism titled 'Sanatana Dharma' (1903) - analogous to Olcott's 'Buddhist Catechism' -, and the 'Universal Textbook of Religion and Morals' (1910), both inspired by Theosophical ideas, as well as those of Hindu reformers. These became required reading for students of the $\mathrm{CHC}$ (for biographical details on Besant, see Taylor 1992).

The essential character of this period in the movement's history can be characterised as a strategic and systematic distribution and institutionalisation of authoritative Hindu-Theosophical knowledge. This happened in reciprocity with the expansion of the Theosophical platform to Indians and the offer of Theosophical hybridised Indian, as well as Western, knowledge to India. Besant's political commitment thus temporarily shaped the interpretation of 'right action' from one's own religious experience and conviction in dealing with the colonial power, a concept that would later compete with those of Gandhi.

The period of Annie Besant's influence as president is characterised by her (late) significant affinity for elitist Brahmanism as well as by an increasing, controlled hierarchical structure (also in the sense of 'esoteric' hierarchies) within the movement and the creation of public cults such as Krishnamurti. It marked a period of religious de-individualisation within the original society and resulted in a great number of schisms and the emergence of opposing groups within the movement. ${ }^{19}$

19 Starting with the separation of TS Adyar and TS America under WQ Judge in 1895. 


\section{Controversies, splits and their consequences within the movement}

Changes in the quality and quantity of religious individualisation within the Theosophical movement should be contextualised and analysed in the context of the movement's history and inner dynamics: after internal loyalty losses caused by the 'Coulomb affair', ${ }^{20}$ Blavatsky founded the 'Blavatsky Lodge' and the so-called 'Esoteric Section' (ES) in London in 1887/88. They represent the ideal of a community of individuals, 'true adepts' ('chelas') who seriously study Theosophy ${ }^{21}$ while rejecting worldly necessities in the form of membership fees, fixed premises, and official membership. Campbell (1980) considers this a consequence of a long standing and fundamental programmatic conflict, and of the 'tension between mysticism and established organization'. In this context, he defines 'mysticism' as 'a type of individualized religious response to the perceived hardening and formalization of religion'. ${ }^{22}$

Notably, the ES models the history, methods, and structures of organisation, as well as the ideals of leadership, for what would later be known as ULT. Moreover, the new organisational forms of these groups are matters of particular interest since they show characteristics of an elitist-spiritual, secret, literally 'esoteric' counterpart to the exoteric side of the movement represented by Besant, Olcott, and Adyar-hierarchies.

In case of the ULT, this concept of the ES is equally the basic requirement for individual spiritual progress. However, the elitist idea, officially formulated by Blavatsky, was omitted and, therefore, no secrecy was required. For the ULT, this resulted in a seemingly paradoxical approach: the adopted form, which was designed by Blavatsky to protect the esoteric parts of Theosophy, was now propagated as a 'method' for stimulating individual spiritual progress, and was thus converted into an exoteric mode. ${ }^{23}$ However, reality is always shaped by individuals.

20 For detailed description and backgrounds of the Coulomb affair, see e.g. Anonymous 1951, 82ff.; Cranston 1993, 265-84; Campbell 1980, 87-95.

21 For Blavatsky's idea of the 'perfect chela', see Anonymous 1951, 136ff.

22 Campbell 1980, 97.

23 This is discussed within the movement and ULT itself, as the question of an anonymous author shows: 'Is ULT, one wonders, trying unsuccessfully to function as an exoteric group within an esoteric form?' The article ULT's Nature and Method - How Esoteric is the Work Of the United Lodge of Theosophists? originates from the ULT-allied Theosophy Magazine, Los Angeles, January 1961, 127-30, 'Question and Comment', online http://www.wisdomworld.org/additional/ Question-AndComment/Number5-January1961.html (last accessed 19th February 2018). 


\section{United Lodge of Theosophists}

Finally, I will try to sketch the 'method' of the United Lodge of Theosophists as (one) climax of spiritual individualisation within the Theosophical movement. In historical perspective, the ULT was a splinter group of the TS in America, under W.Q. Judge's presidency after its separation from the TS Adyar. Its founder, Robert Crosbie, was a former member of the TS in Boston. Born into a largely Protestant environment, he was, like most other founders, exposed to spiritualism from a young age. The aforementioned affinity in the TS with the rising desire for scientific study of the paranormal as well as Oriental Studies that was prominent in America co-occurred in the life sciences as well as in (academic) psychology, with the same basic interest, but from different starting points. ${ }^{24}$

These different backgrounds should be kept in mind when looking more closely at the 'method' of the ULT, which in terms of religious individualisation can be reduced to its essential features ${ }^{25}$ and summarised as:

1) The programmatic rejection of structures of organisation, as described in the previous section on the Esoteric Section and Blavatsky Lodge. The only requirement for associates is the agreement to the so-called 'Declaration'. As stated on their website, 'A brief philosophic declaration is its sole guiding document'. ${ }^{26}$ The prevalence of forms and (hierarchical) structures is

24 Thus, the prominent TS member William James, who entered the Lodge of the TS in Boston in the same year as Robert Crosbie, shows in his works profound knowledge of the Theosophical doctrine when he identifies the Indian Vedānta philosophy as one of their fundamental concepts. Taylor 2009, 36 with reference to an article by William James on the meaning of 'person and personality' in Johnson's Universal Cyclopedia, New York, 1893.

25 A detailed description by the ULT itself with appropriate statements can be found in the Pamphlet The United Lodge of THEOSOPHISTS. Its Mission and Its Future. Online: http://www.phxult-lodge.org/amission.htm (last accessed 19th February 2018).

26 The text reads as follows: 'Declaration: The policy of this Lodge is independent devotion to the cause of Theosophy, without professing attachment to any Theosophical organization. It is loyal to the great Founders of the Theosophical movement, but does not concern itself with dissensions or differences of individual opinion. The work it has on hand and the end it keeps in view are too absorbing and too lofty to leave it the time or inclination to take part in side issues. That work and that end is the dissemination of the fundamental principles of the Philosophy of Theosophy, and the exemplification in practice of those principles, through a truer realization of the SELF; a profounder conviction of Universal Brotherhood. It holds that the unassailable basis for union among Theosophists, wherever and however situated, is "similarity of aim, purpose and teaching," and therefore has neither Constitution, By-Laws nor Officers, the sole bond between its Associates being that basis. And it aims to disseminate this idea among Theosophists in the furtherance of Unity. It regards as Theosophists all who are engaged in the true service of Humanity, without distinction of race, creed, sex, condition or organization, and It welcomes to 
regarded as a main cause for turning away from the essential: the pure study of Theosophy and self-awareness of the individual as part of the Universal Brotherhood, also regarded as potential unity with the Divine.

2) Access to divine wisdom with the higher self via rejection of any personalisation of teachings and connected personal cults, which are seen as obstacles for overcoming the 'illusion of self'. Emphasised keywords are therefore 'impersonality', 'anonymity', and, as a consequence, 'esotericity'. Here, 'impersonality' and its meaning 'anonymity' function as protection for each individual as a part of a whole: only by eliminating the obstacle of the 'illusion of self' can the individual achieve personal access to divine wisdom. It is the only way to become a specific, individual part of the theosophical organism, the 'Universal Brotherhood', according to one's own karma and through consistent development of one's higher self. This should, however, not be confused with a selfish quest for knowledge and progress which is not conscious of the perpetual connection between the individual and the whole.

3) The absolute necessity of independent study and individual comprehension of the original sources and the movement's history, and, in consequence, the availability of original materials. In addition, the need for the study of the philosophy and history of the Theosophical movement for everyone's own independent comprehension of the original teachings, as well the familiarity with the writings of Blavatsky, Crosbie, Judge, Wadia and other ULT-writers.

4) Independent, practical application of the 'third objective' of the Theosophical Movement, 'to investigate unexplained laws of nature and psychic and spiritual powers latent in man'.

5) The ideal of the inspired, 'magnetic' individual as a permanent potential nucleus/centre to spread (theosophical) wisdom invisible to others. Such an individual requires spiritual integrity as a potential founder and the centre of a study group, whose members he can influence positively by invisible forces to make them better people and to spread his influence, again 'invisible', to other circles.

\footnotetext{
its association all those who are in accord with its declared purposes and who desire to fit themselves, by study and otherwise, to be the better able to help and teach others. "The true Theosophist belongs to no cult or sect, yet belongs to each and all."' Further, there is a form to sign by associates: "Being in sympathy with the purposes of this Lodge, as set forth in its "Declaration", I hereby record my desire to be enrolled as an Associate, it being understood that such association calls for no obligation on my part, other than that which I, myself, determine'. http://www.ult.org/ (last accessed 19th February 2018).
} 
These criteria emphasise without exception the pursuit of the individual and its perfection, meant as a process of unification with the Divine or the higher self, as well as with the community of like-minded persons, but each in their own vital way. Here, all of the features above are methods for the ultimate elimination of irritation that prevents associates from studying and spreading the true teachings of Blavatsky, regarded as a manifestation of divine wisdom. An essential point, however, is the realisation of one's own, individual path and its necessity. Generally speaking, increasing institutionalisation within the Theosophical Movement is regarded as diminishing the space for individual approaches, leading to splinter groups claiming individual approaches as their main original objective. However, as in most 'religious/spiritual programs', there is a natural and fundamental tension between ideals and realities.

\section{Conclusion}

The obvious potential offered by the original TS is in decline - in its motherland as well as in other countries such as India - due to the increasing hierarchy and dogma within the movement. This trend resulted in, among other things, the separation of the United Lodge of Theosophists (ULT) in Los Angeles in 1909. The concepts and backgrounds of this splinter group can, again, be seen as the result of several processes in the TS, such as the founding of the Esoteric Section (ES) by Blavatsky herself in 1888. The ES was supposed to take shape as an elitist secret society and was directed by Blavatsky at 'true adepts'. These are distinguished from mere blind followers for the purpose of individual study of 'real' Theosophy. The 'esoteric form' of the ES presents itself in many ways as a model for the organisational structure of the ULT. The latter consciously understands established organisational forms as obstacles to an individual search for truth. Particularly remarkable as characteristics are the principles of a) emphasis on the inner self, b) impersonality and anonymity, c) 'esotericity', as well as d) the idea of 'each member a centre'. They show a permanent call for the individual's representation and his or her responsibility for the 'soul of the whole body', which is supported by very few regulations and generally rejects administrative control. The ULT's programmatic individual approach to Helena Blavatsky's theosophy is based solely on one's own experience and selfstudy and explicitly rejects any form of organisation, institutionalisation, hierarchies, or dogma. With its strict emphasis on the writings of Blavatsky and her 'true disciples', William Quan Judge, Robert Crosbie, and B.P. Wadia, the ULT - an organisation of American origin and refined in India, among other countries - carries a certain echo of the 'sola scriptura' feature of Protestant religions. 
The ULT India was founded in 1929 by the Indian Parsee B.P. Wadia. This year marks at the same time with the resignation of Krishnamurtis the beginning of the "Post-Gilded Age" of TS Adyar. ULT India could possibly have acted here as a trigger, preserver, or even destroyer of religious individualisation in the context of the Theosophical Society Adyar in India.

The history of splits and schisms within the Theosophical Movement and, ultimately, the foundation of the ULT provides some general insights into the dynamics of individualisation processes, both (a) within the movement, structurally as in self-understanding, as well as (b) specifically in India in reciprocity with indigenous religions, colonial perceptions, and political involvement.

\section{References}

Albanese, Catherine L. 2007. A Republic of Mind and Spirit. A Cultural History of American Metaphysical Religion. New Haven: Yale University Press.

Altschuler, Glenn C. and Jan M. Saltzgaber. 1983. Revivalism, Social Conscience, and Community in the Burned-over District: the Trial of Rhoda Bement. Ithaca: Cornell University Press.

Anonymous. 1951. History of the Theosophical Movement 1875-1950. The Cunningham Press. Online: http://www.phx-ult-lodge.org/theosophica\%20lmovement.html (last accessed 9th August 2018).

Anonymous, 2018. Objects of the Theosophical Society. http://theosophy.wiki/w-en/index. php?title=Objects_of_the_Theosophical_Society (last accessed 5th August 2018)

Bechert, Heinz. 1995'. 'Die Erneuerung des asiatischen und die Entstehung des abendländischen Buddhismus'. In Der Buddhismus. Die Welt des Buddhismus. Geschichte und Gegenwart, eds. Heinz Bechert und Richard Gombrich, München: Beck, 336-63.

Bergunder, Michael. 2006. 'Die Bhagavadgita im 19. Jahrhundert. Hinduismus, Esoterik und Kolonialismus'. In Westliche Formen des Hinduismus in Deutschland. Eine Übersicht, ed. idem, Halle: Verlag der Franckeschen Stiftungen. 187-217.

Bevir, Mark. 1994. 'The West Turns Eastward: Madame Blavatsky and the Transformation of the Occult Tradition', Journal of the American Academy of Religion 62.3. 747-67.

Blavatsky, Helena P. 1888. The Secret Doctrine: The Synthesis of Science, Religion and Philosophy. 2 vols. London: Theosophical Publishing Society.

Blum, Deborah. 2006. Ghost Hunters: William James and the search for scientific proof of life after death. New York: Penguin Press.

Braude, Ann D. $2001^{2}$. Radical Spirits: Spiritualism and Women's Rights in Nineteenth-Century America. Bloomington: Indiana University Press.

Campbell, Bruce F. 1980. Ancient Wisdom Revived. A History of the Theosophical Movement. Berkeley: University of California Press.

Carroll, Bret E. 1997. Spiritualism in Antebellum America. Bloomington: Indiana University Press.

Christy, Arthur. 1932. The Orient in American Transcendentalism. A Study of Emerson, Thoreau, and Alcott. New York: Columbia University Press.

Claybaugh, Amanda. 2007. The Novel of Purpose. Literature and Social Reform in the Anglo-American World. Ithaca: Cornell University Press. 
Cranston, Sylvia. 1993. The Extraordinary Life and Influence of Helena Blavatsky, Founder of the Modern Theosophical Movement. New York: Putnam.

Cross, Whitney R. 1950. The Burned-over District: The Social and Intellectual History of Enthusiastic Religion in Western New, 1800-1850. Ithaca: Cornell University Press.

Doyle, Arthur C. 1926. The History of Spiritualism. 2 vols. London: Cassell.

Godwin, Joscelyn. 1994. The Theosophical Enlightenment. Albany: State University of New York Press.

Goodrick-Clarke, Nicholas (ed.). 2004. Helena Blavatsky. Berkeley: North Atlantic Books.

Goodrick-Clarke, Nicholas. 2013. 'Western Esoteric Traditions and Theosophy'. In Olav Hammer and Mikael Rothstein (eds.). 261-308.

Haas, Cornelia. 2012. 'Mme. Blavatsky, Max Müller und die göttliche Weisheit des alten Indien'. In 200 Jahre Indienforschung: Geschichte(n), Netzwerke, Diskurse, eds. Heidrun Brückner and Karin Steiner, Wiesbaden: Harrassowitz. 181-95.

Haas, Cornelia. 2015. 'From Theosophy to Buddhism'. In Individualisierung durch christliche Mission?, eds. Martin Fuchs, Antje Linkenbach and Wolfgang Reinhard, Wiesbaden: Harrassowitz. 504-19.

Haas, Cornelia. forthcoming. 'Diskurse über die Evolution von Mensch und Sprache in Helena Blavatskys Anthropogenesis (Secret Doctrine II)'. In Max Müller (1823-1900). Diesseits und Jenseits von Philologie, Mythologie und Religionswissenschaft, eds. Andreas Nehring und Roger Thiel. Manuscript submitted for publication. Preprint on academia.edu: https://www.academia.edu/33256202/Preprint_Sprachevolution_bei_Blavatsky-Kopie. pdf (last accessed 14th February 2018).

Hammer, Olav. 2009. 'Schism and consolidation: the case of the theosophical movement'. In Sacred Schisms: How Religions divide, eds. James R. Lewis and Sarah M. Lewis, New York: Cambridge University Press. 196-217.

Hammer, Olav. 2015. 'Theosophy'. In The Occult World, ed. Christopher Partridge, London: Routledge. 50-9.

Hammer, Olav and Mikael Rothstein (eds.). 2013. Handbook of the Theosophical Current. Leiden: Brill.

Hick, John. $1990^{6}$. Death and eternal life. San Francisco: Harper and Row.

Keller, Ursula and Natalja Sharandak. 2013. Madame Blavatsky. Eine Biographie. Berlin: Insel Verlag.

Lubelsky, Isaac. 2012. Celestial India. Madame Blavatsky and the Birth of Indian Nationalism. Sheffield: Equinox Publishing.

Moritz, Maria S. 2017. Globalizing 'Sacred Knowledge': South Asians and the Theosophical Society (1879-1930). PhD-Thesis (History) Jacobs University Bremen 2012. [First published: IRC-Library, Information Resource Center der Jacobs University Bremen 08.05.2017. URL: http://nbn-resolving.de/urn:nbn:de:gbv:579-opus-1007032 (last accessed 19th February 2018)].

Obeyesekere, Gananath. 1970. 'Religious Symbolism and Political Change in Ceylon', Modern Ceylon Studies 1. 43-63.

Oppenheim, Janet. 1988. The Other World: Spiritualism and Psychical Research in England, 1850-1914. Cambridge: Cambridge University Press.

Pritchard, Linda K. 1984. 'The burned-over district reconsidered: A portent of evolving religious pluralism in the United States', Social Science History 8.3. 243-65.

Prothero, Stephen R. 1995. 'Henry Steel Olcott and “Protestant Buddhism”, Journal of the American Academy of Religion 63.2. 281-302. 
Prothero, Stephen R. 1996. The White Buddhist: The Asian Odyssey of Henry Steel Olcott. Bloomington: Indiana University Press.

Queen, Christopher S. 1996. 'Introduction: The Shapes and Sources of Engaged Buddhism'. In Engaged Buddhism. Buddhist Liberation Movements in Asia, eds. idem and Sallie B. King, Albany: State University of New York Press.

Schlerth, Thomas J. 1991. Victorian America: Transformations in Everyday Life, 18761975. New York: Harper Collins.

Stausberg, Michael. 2002. Die Religion Zarathushtras. Geschichte - Gegenwart - Rituale. Volume 1: Geschichte. Stuttgart: Kohlhammer.

Sutherland, Daniel E. 1989. The Expansion of Everyday Life: 18601876. New York: Harper and Row.

Taylor, Eugene. 1983. William James on exceptional mental states. New York: Scribner.

Taylor, Eugene. 1999. Shadow culture: psychology and spirituality in America. Washington: Counterpoint.

Taylor, Eugene. 2007. 'Review of "Ghost Hunters: William James and the search for scientific proof of life after death. By Deborah Blum. New York: Penguin, 2006"',William James Studies 2: http://williamjamesstudies.org/ghost-hunters-william-james-andthe-search-for-scientific-proof-of-life-after-death-by-deborah-blum/(last accessed 19th February 2018).

Taylor, Eugene. 2009. The Mystery of Personality. A History of Psychodynamic Theories. New York: Springer-Verlag.

Thanissaro, Bhikkhu. 1994. Kalama Sutta: To the Kalamas (AN 3.65). trans. from the Pali by idem: http://www.accesstoinsight.org/tipitaka/an/an03/an03.065.than.html (last accessed 19th February 2018).

Trochu, Thibaud. 2008. 'Investigations into the William James Collection at Harvard: An interview with Eugene Taylor’, William James Studies 3: http://williamjamesstudies. org/investigations-into-the-william-james-collection-at-harvard-an-interview-witheugene-taylor/ (last accessed 19th February 2018).

Von Stuckrad, Kocku. 2014. The Scientification of Religion: An Historical Study of Discursive Change, 1800-2000. Berlin: De Gruyter.

Wellman, Judith. 2000. Grassroots Reform in the Burned-over District of Upstate New York: Religion, Abolitionism, and Democracy. New York: Garland Publishing. 